\title{
Effect of Date of Transplanting and Crop Geometry on Growth and Physiological Attributes of Capegooseberry (Physalis peruviana L.)
}

\author{
Sarita Bagri*, Jitendra Singh, Prerak Bhatnagar, Gayatri Khatik, \\ S.K. Jainand Kamlesh Kumar Meena \\ College of Horticulture \& Forestry, Jhalrapatan, Jhalawar (326023), India \\ *Corresponding author
}

\section{A B S T R A C T}

\begin{tabular}{|c|}
\hline Keywords \\
\hline $\begin{array}{l}\text { Date of transplanting, } \\
\text { Spacing, Variety, } \\
\text { Growth, } \\
\text { Capegooseberry }\end{array}$ \\
\hline Article Info \\
\hline $\begin{array}{l}\text { Accepted: } \\
\text { 24 September } 2018 \\
\text { Available Online: } \\
10 \text { October } 2018\end{array}$ \\
\hline
\end{tabular}

An experiment was conducted to evaluate effect of date of transplanting and crop geometry on growth, yield and quality of capegooseberry (Physalis peruviana L.) at farm of College of Horticulture and Forestry, Jhalrapatan, Jhalawar during 2016-17. The experiment was laid out in Split Plot Design comprising with 60 treatment combination of ten varieties [Amb. Sel.-1, Amb.Sel.-2, Amb.Sel.-3, Amb.Sel.-4, Amb.Sel.-5, Amb.Sel.-6, Amb. Sel.-7, Selection-7, Selection-9 and Selection-21] taken in main plot and three date of transplanting [15th September $\left(D_{1}\right), 30^{\text {th }}$ September $\left(D_{2}\right)$ and $15^{\text {th }}$ October $\left(D_{3}\right)$ ] and two spacing $\left[90 \times 60 \mathrm{~cm}\left(\mathrm{~S}_{1}\right)\right.$ and $\left.60 \times 60 \mathrm{~cm}\left(\mathrm{~S}_{2}\right)\right]$ in sub plots and replicated with three replication. The results of the experiment showed that maximum plant height $(89.30 \mathrm{~cm})$, E-W $(88.03 \mathrm{~cm})$ as well as N-S $(86.89 \mathrm{~cm})$ plant spread, chlorophyll content of leaves $(2.62$ $\mathrm{mg} / 100 \mathrm{~g})$, leaf perimeter $(34.17 \mathrm{~cm})$, leaf length $(12.54 \mathrm{~cm})$ and leaf breadth $(10.25 \mathrm{~cm})$ were obtained at $30^{\text {th }}$ September $\left(\mathrm{D}_{2}\right)$ transplanting date. The spacing of $90 \times 60 \mathrm{~cm}\left(\mathrm{~S}_{1}\right)$ gave maximum E-W as well as N-S plant spread, leaf perimeter, leaf length, leaf breadth, leaf shape and $60 \times 60 \mathrm{~cm}\left(\mathrm{~S}_{2}\right)$ spacing gave maximum plant height.

\section{Introduction}

Capegooseberry (Physalis peruviana L.) belongs to the family of Solanaceae. Its somatic chromosomes number $2 n=24$. It is the only important annual herbaceous, minor tropical fruit crop of India. The crop has potential for use as nutraceutical (Ramadan and Morsel, 2007) besides as a fresh fruit. It is known by various names like Mokai, Bhutka, Rasbhari, ground tomato, ground cherry, husk tomato etc. The crop is native to South America (Klinac, 2012). In agriculture production system the crop holds significance particularly for its seasonal and quick growing nature, non-perennial occupation of land and comparatively dwarfs nature. Notwithstanding beneficial aspects, the cultivation of capegooseberry is restricted to a limited area in our country.

Lack of proper package of practices, area specific suitable genotype, lack of popularity etc. is major bottleneck in increasing its yield, economics and also the area (Girapu and Kumar, 2006). The fruit is a berry with smooth, waxy, orange yellow skin (Legge, 1974). 
Optimum plant spacing ensures proper growth and development of plants resulting in maximum yield and economic use of land. However, there are no reports regarding optimum sowing date and spacing for the successful cultivation of capegooseberry, especially under the agro-climatic conditions of Rajasthan.

The present investigation thus designed to find out the most suitable sowing time and spacing to achieve higher yield and quality fruit in capegooseberry (Dwivedi et al., 2015).

The variation in planting time may also affect the plant vigour and spread which further affect the yield and thus the crop requires variable spacing. Optimum plant spacing ensures proper growth and development of plant resulting in maximum yield of the crop and the best use of land.

\section{Materials and Methods}

The present investigation was carried out at the Farm of College of Horticulture and Forestry Jhalraparan, Jhalawar during 201617. The experiment was laid out in Split Plot Design comprising with 60 treatment combination of ten varieties [Amb. Sel.-1, Amb.Sel.-2, Amb.Sel.-3, Amb.Sel.-4, Amb.Sel.-5, Amb.Sel.-6, Amb. Sel.-7, Selection-7, Selection-9 and Selection21]taken in main plot and three date of transplanting $\left[15\right.$ th September $\left(\mathrm{D}_{1}\right), 30^{\text {th }}$ September $\left(\mathrm{D}_{2}\right)$ and $15^{\text {th }}$ October $\left.\left(\mathrm{D}_{3}\right)\right]$ and two spacing $\left[90 \times 60 \mathrm{~cm}\left(\mathrm{~S}_{1}\right)\right.$ and $60 \times 60 \mathrm{~cm}$ $\left(\mathrm{S}_{2}\right)$ ] in sub plots and replicated with three replication. Regular cultural operation, irrigation, plant protection measures was done according to the need of crop. The observation were recorded on plant height $(\mathrm{cm}), \mathrm{E}-\mathrm{W}$ as well as N-S plant spread $(\mathrm{cm})$, chlorophyll content of leaves $(\mathrm{mg} / 100 \mathrm{~g})$, leaf length $(\mathrm{cm})$, leaf breadth $(\mathrm{cm})$, leaf perimeter $(\mathrm{cm})$. Data on different characters were recorded and analyzed statistically as described by Pance and Sukhatme (1967) for Split Plot Design.

\section{Results and Discussion}

\section{Effect of date of transplanting and spacing on growth and physiological attributes of different varieties of capegooseberry}

Amongst all the varieties maximum plant height was noted in Amb. Sel.-4 $(99.89 \mathrm{~cm})$ and minimum plant height was observed in Selection-7 $(58.57 \mathrm{~cm})$. Maximum E-W $(146.10 \mathrm{~cm})$ as well as N-S $(149.20 \mathrm{~cm})$ plant spread was noted in Selection-21 while minimum plant spread E-W (60.93 CM) was noted in Amb. Sel.-5 and plant spread N-S $(59.91 \mathrm{~cm})$ was recorded in Amb. Sel.-7. Maximum chlorophyll content of leaves (3.21 $\mathrm{mg} / 100 \mathrm{~g}$ ) was noted in Selection-7 and minimum (1.98 mg/g) in Amb. Sel.-2. Maximum leaf perimeter $(40.57 \mathrm{~cm})$ was noted in Amb. Sel.-3 and minimum (17.16 $\mathrm{cm})$ was noted in Selection-21. Maximum leaf length $(13.69 \mathrm{~cm})$ as well as leaf breadth $(11.93 \mathrm{~cm})$ was noted in Amb. Sel.-4 while minimum leaf length $(8.36 \mathrm{~cm})$ was noted in Selection-21. Minimum leaf breadth was noted in Selection-7 (4.13) Transplanting date significantly influenced the plant height.

The effect of date of transplanting on plant height $(89.30 \mathrm{~cm}), \mathrm{E}-\mathrm{W}(88.03 \mathrm{~cm})$ as well N$\mathrm{S}(86.89 \mathrm{~cm})$ plant spread, Leaf perimeter $(34.17 \mathrm{~cm})$, leaf length $(12.54 \mathrm{~cm})$ and leaf breadth $(10.25 \mathrm{~cm})$ was found maximum with the $30^{\text {th }}$ September $\left(D_{2}\right)$ date of transplanting. Whereas, the minimum plant height (77.97 $\mathrm{cm})$, E-W $(82.16 \mathrm{~cm})$ as well N-S $(84.42 \mathrm{~cm})$ plant spread, Leaf perimeter $(32.39 \mathrm{~cm})$, leaf length $(11.04 \mathrm{~cm})$ and leaf breadth $(8.54 \mathrm{~cm})$ was recorded in $15^{\text {th }}$ October date of transplanting. The maximum Chlorophyll content of leaves $(2.62 \mathrm{mg} / 100 \mathrm{~g})$ was recorded in $30^{\text {th }}$ September $\left(\mathrm{D}_{2}\right)$ with $15^{\text {th }}$ October $\left(\mathrm{D}_{3}\right)$ transplanting (Table 1$)$. 
Table.1 Effect of date of transplanting and crop geometry on growth and physiological attributes of capegooseberry (Physalis peruviana L.)

\begin{tabular}{|c|c|c|c|c|c|c|c|}
\hline \multirow[t]{2}{*}{ Treatments } & \multirow{2}{*}{$\begin{array}{l}\text { Plant } \\
\text { height } \\
(\mathrm{cm})\end{array}$} & \multicolumn{2}{|c|}{ Plant spread (cm) } & \multirow{2}{*}{$\begin{array}{l}\text { Chlorophyll } \\
\text { content of } \\
\text { leaves } \\
\text { (mg/100g) }\end{array}$} & \multirow{2}{*}{$\begin{array}{l}\text { Leaf } \\
\text { peri } \\
\text { meter } \\
(\mathrm{cm})\end{array}$} & \multirow{2}{*}{$\begin{array}{l}\text { Leaf } \\
\text { length } \\
(\mathrm{cm})\end{array}$} & \multirow{2}{*}{$\begin{array}{l}\text { Leaf } \\
\text { width } \\
(\mathrm{cm})\end{array}$} \\
\hline & & E-W & $\mathrm{N}-\mathrm{S}$ & & & & \\
\hline Amb.Sel.-1 & 94.33 & 69.24 & 64.43 & 2.40 & 38.79 & 12.93 & 10.84 \\
\hline Amb.Sel.-2 & 86.11 & 66.78 & 71.21 & 1.98 & 38.69 & 12.35 & 10.75 \\
\hline Amb.Sel.-3 & 97.23 & 73.82 & 74.36 & 2.78 & 40.57 & 13.42 & 11.78 \\
\hline Amb.Sel.-4 & 99.89 & 70.82 & 75.39 & 2.32 & 39.57 & 13.69 & 11.93 \\
\hline Amb.Sel.-5 & 81.91 & 60.93 & 60.29 & 2.53 & 34.46 & 12.00 & 9.15 \\
\hline Amb.Sel.-6 & 87.57 & 64.98 & 62.54 & 2.51 & 36.37 & 12.19 & 11.09 \\
\hline Amb.Sel.-7 & 84.00 & 61.76 & 59.91 & 2.30 & 38.83 & 13.49 & 11.88 \\
\hline Selection.-7 & 58.57 & 121.71 & 121.18 & 3.21 & 23.22 & 9.32 & 4.13 \\
\hline Selection-9 & 69.39 & 116.45 & 118.37 & 3.20 & 25.40 & 10.25 & 6.28 \\
\hline Selection-21 & 70.76 & 146.10 & 149.20 & 2.93 & 17.16 & 8.36 & 5.57 \\
\hline SEm+ & 1.771 & 0.787 & 0.708 & 0.082 & 1.052 & 0.365 & 0.321 \\
\hline CD at $5 \%$ & 5.263 & 2.337 & 2.105 & 0.243 & 3.126 & 1.084 & 0.953 \\
\hline \multicolumn{8}{|c|}{ Sub plot: Transplanting date } \\
\hline $15^{\text {th }}$ September & 81.64 & 85.59 & 85.76 & 2.61 & 33.36 & 11.82 & 9.24 \\
\hline $30^{\text {th }}$ September & 89.30 & 88.03 & 86.89 & 2.62 & 34.17 & 12.54 & 10.25 \\
\hline $15^{\text {th }}$ October & 77.97 & 82.16 & 84.42 & 2.62 & 32.39 & 11.04 & 8.54 \\
\hline SEm+ & 1.147 & 0.627 & 0.467 & 0.029 & 0.397 & 0.170 & 0.166 \\
\hline CD at $5 \%$ & 3.218 & 1.758 & 1.310 & 0.080 & 1.114 & 0.476 & 0.467 \\
\hline \multicolumn{8}{|c|}{ Sub plot: Spacing } \\
\hline $90 \times 60 \mathrm{~cm}$ & 82.17 & 87.45 & 87.74 & 2.62 & 11.81 & 9.35 & 11.81 \\
\hline $60 \times 60 \mathrm{~cm}$ & 83.77 & 83.07 & 83.63 & 2.61 & 11.79 & 9.33 & 11.79 \\
\hline SEm+ & 0.937 & 0.512 & 0.381 & 0.023 & 0.138 & 0.136 & 0.138 \\
\hline $\mathrm{CD}$ at $5 \%$ & 2.628 & 1.435 & 1.070 & 0.065 & 0.388 & 0.381 & 0.388 \\
\hline
\end{tabular}

The effect of spacing on plant height $(83.77 \mathrm{~cm})$ was noted maximum with the $60 \times$ $60 \mathrm{~cm}\left(\mathrm{~S}_{2}\right)$ spacing and minimum plant height $(82.17 \mathrm{~cm})$ was recorded under $90 \times 60 \mathrm{~cm}$ $\left(\mathrm{S}_{1}\right)$ spacing.

The maximum E-W $(87.45 \mathrm{~cm})$ as well as N-S $(87.74 \mathrm{~cm})$ plant spread, chlorophyll content of leaves $(2.62 \mathrm{mg} / 100 \mathrm{~g})$, leaf perimeter $(33.39 \mathrm{~cm})$, leaf length $(11.81 \mathrm{~cm})$ and leaf breadth $(9.35 \mathrm{~cm})$ was observed in $90 \times 60 \mathrm{~cm}$ $\left(\mathrm{S}_{1}\right)$ spacing. That earlier planting date performed better in terms of growth because the crop gets enough duration to complete the vegetative phase fully reported by Hamma et al., (2012). More height in the plant at closer spacing $60 \times 60 \mathrm{~cm}$ might be due to competitive growth behavior of plant over other plants to get more and more sunlight Faiza et al., (2002) reported increased plant height of bell pepper with the closer spacing. Wider spacing $90 \times 60 \mathrm{~cm}$ most of the growth attributes were found better.

With increase in spacing there had been more vegetative growth. Such result has been reported by Pawar and Karale (1997) in tomato. 


\section{References}

Dwivedi, D. H., Rao, S., Gautam, S. K., Kumar, P. (2015) Effect of sowing time and spacing on the performance of capegooseberry (Physalis peruviana L.) in central Uttar Pradesh. Hortflora Research Spectrum, 4 (1) 67-69.

Faiza, A., Muhaammad, I., Wadan, H. D. and Shah, M. (2002) Effect of different levels of nitrogen and plant spacing on the growth and yield of sweet pepper cv. Yellow Wonder Sharad Journal of Agriculture, 18 (3) : 275279.

Girapu, R. K. and Kumar, A. (2006) Influence of nitrogen and spacing on growth, yield and economics of capegooseberry (Physalis peruviana L.) production. Proceedings of national symposium on production, utilization and export of underutilized fruits with commercial potentialities held at Bidhan Chandra Krishi Vishwavidyalaya, West Bengal, November 22-24, 2006.

Hamma, I.L., Ibrahim, U. and Haruna, M. (2012) Effect of planting date and spacing on the growth and yield of sweet pepper (Capsicum annuum L.) in samara area of Zaria in Nigeria.
Nigerian J. Agric. Food and Env., 8:6366

Klinac, D. J. (2012) Capegooseberry (Physalis peruviana L.) production systems. New Zealand Journal of Experiment Agriculture, 14 (4): 425430.

Legge, A. P. (1974) Notes on history, cultivation and use of Physalis peruviana L. Journal RoyalHort. Soci. (UK), 99: 310-314.

Moldoveanu, L. (1977) Space per plant and planting layout of early tomatoes grown without stakes. Gradinarska I LozarskaNauka, Bulgaria, 14 (4): 73 83.

Pancse, V. G. and Sukhatme, p. v. (1967) Statistical Methods for Agricultural Workers. Indian Council of Agricultural Research, Published by ICAR New Delhi.

Pawer, S. D. and Karale, A. R. (1997) Effect of different levels of nitrogen and spacing on growth and yield of tomato (Lycopersicon esculentum Mill.) Var. Utkal Kumari. Haryana J.Hort. Sci., 31 (3 and 4): 264-266.

Ramadan, M. F. and Morsel, J. T. (2007) Golden berry A Novel fruit source of fat soluble bioactive. INFORM. 15130-131.

\section{How to cite this article:}

Sarita Bagri, Jitendra Singh, Prerak Bhatnagar, Gayatri Khatik, S.K. Jain, and Kamlesh Kumar Meena. 2018. Effect of Date of Transplanting and Crop Geometry on Growth and Physiological Attributes of Capegooseberry (Physalis peruviana L.). Int.J.Curr.Microbiol.App.Sci. 7(10): 3203-3206. doi: https://doi.org/10.20546/ijcmas.2018.710.371 